\title{
The impact of mining activities on the sediment quality in water reservoir Ruzin I. (Slovakia)
}

\author{
Eva Singovszka, Aneta Petrilakova, Magdalena Balintova, Marian Holub \\ Technical University of Kosice, Faculty of Civil Engineering, Vysokoskolska 4, 04200 Kosice, Slovakia \\ aeva.singovszka@tuke.sk, ${ }^{b}$ marian.holub@tuke.sk
}

\begin{abstract}
The contaminationof aquatic and terrestrial ecosystems with heavy metals and other mining chemicals have been major environmental problems in manymining areas of the world. The peak period of metal mining was from the middle to late nineteenth century, although from many sites the pollution continues also at present. In such catchments, almost 90 per cent of the metals are associated rather with sediment than in aqueous forms, and the metal pollutants are primarily mobilised and transported downstream, and deposited in lakes or dams.

Water reservoir Ruzin I. is situated in territory, which is well-known by its mining and metallurgical history for several centuries, such as ore deposit Smolnik. Surface water from this area is contaminated by acid mine drainage (AMD) outflowed from abandoned sulphide mine Smolnik. AMD with low value of the $\mathrm{pH}$ (about 3-4) is a result of chemical oxidation of sulphides and other chemical processes in mine. The $\mathrm{pH}$ increasing due to the mixture AMD with surface water is followed by metal precipitation and its sedimentation in water environment. Contaminated sediment is transported by erosion processes into the river Hnilecand then into water reservoir Ruzin.

The aim of this work was to evaluate the chemical quality of the sediment influenced by the mining activities and to assess the present and future potential risks of acid mine drainage to the water reservoir Ruzin I. (Slovakia) by the enrichment factor and pollution load index.
\end{abstract}

Keywords: acid mine drainage; heavy metals; enrichment factor; water reservoir Ruzin; Slovakia.

\begin{tabular}{|ll|}
\hline Nomenclature \\
$A M D$ & acid mine drainage \\
$E F$ & enrichment factor \\
$M_{c}$ & content of contaminants \\
$M_{r}$ & content of reference elements \\
$S$ & sample \\
$b$ & background concentration \\
\hline
\end{tabular}

\section{Introduction}

Potentially harmful metal contamination of sediment, soil and groundwater is one of the most substantial threats to environmental quality and human health. High concentrations of these metals are released into the aquatic environment as a result of leaching from bedrocks, atmospheric deposition, drainage, runoff from riverbanks, and discharge of urban and industrial wastewaters [1]. Mining activities are often associated with environmental impacts including metal contamination of sediments and aquatic systems [2]. Water reservoir Ruzin (Slovakia) (Fig. 1) located in east Slovakia (situated on the Hornad river) is one of the most contaminated sites by heavy metals coming from abandoned metallurgical mines produced acid mine drainage (AMD). These acidic waters, which frequently contain high concentrations of heavy metals, often have adverse effect on the quality and ecology of waters receiving the effluent [3], [4].Studies of the creeksinfluenced by AMD have detected high concentrations of contaminant metals $(\mathrm{Cu}, \mathrm{Fe}, \mathrm{Mn}, \mathrm{As}, \mathrm{Zn}$ and $\mathrm{Pb})$ in the water and sediment [5]. When the metals concentration exceeds standard permissible limits, it would have toxic effects on livingorganisms and cause negative impact on lower life forms. For example, transition metals such as copper ( $\mathrm{Cu})$, zinc $(\mathrm{Zn})$, cobalt (Co), manganese $(\mathrm{Mn})$, nickel $(\mathrm{Ni})$, and iron (Fe) are essential nutrients; however, they may be toxic if in high concentration. Thesemetals

Corresponding author: Marian Holub. E-mail address: marian.holub@tuke.sk

http://dx.doi.org/10.3846/enviro.2014.091

(C) 2014 The Authors. Published by VGTU Press. This is an open-access article distributed under the terms of the Creative Commons Attribution License, which permits unrestricted use, distribution, and reproduction in any medium, provided the original author and source are credited. 
enter the environment and are distributed between the aqueous phase and the suspended sediments during their transport [6]. Metals tend to be assimilated in sediment with organic matter, Fe/Mn oxides, sulphide, and clay thus forming several reactive components, which are harmful to the environment. Hence, sediment is always regarded as the potential reservoir for metals and plays an important role in adsorption of dissolved heavy metals [7], [8].

Water reservoir Ruzin was constructed in order to ensure water for metallurgical and other industrial purposes, for dilution of waste water, the flattening of flood flows, to generate electricity, and is also used for recreation [9]. Ruzin consist of two water reservoirs. The mainreservoirRuzinI.builtin1967has a capacity of59 million meters cubic and expansion tank Ruzin II., which was completedin 1972. Bottom sediments from this reservoir are contaminated above all by heavy metals, which are alluvial into the reservoir from localities of former activities and thus they represent ecological load mainly at the inputs into reservoir. Enhanced contents of heavy metals hinder in direct application of sediments in agriculture, building and field engineering. For this reason it is needed to search for suitable ways of bottom sediments decontamination [10-12].

In this study of environmental contamination, a common approach to estimate how much the sediments is impacted (naturally or anthropogenically) with heavy metals is to evaluate the Enrichment factor (EF) and Pollution load index (PLI) for metal concentrations above uncontaminated background or reference levels.

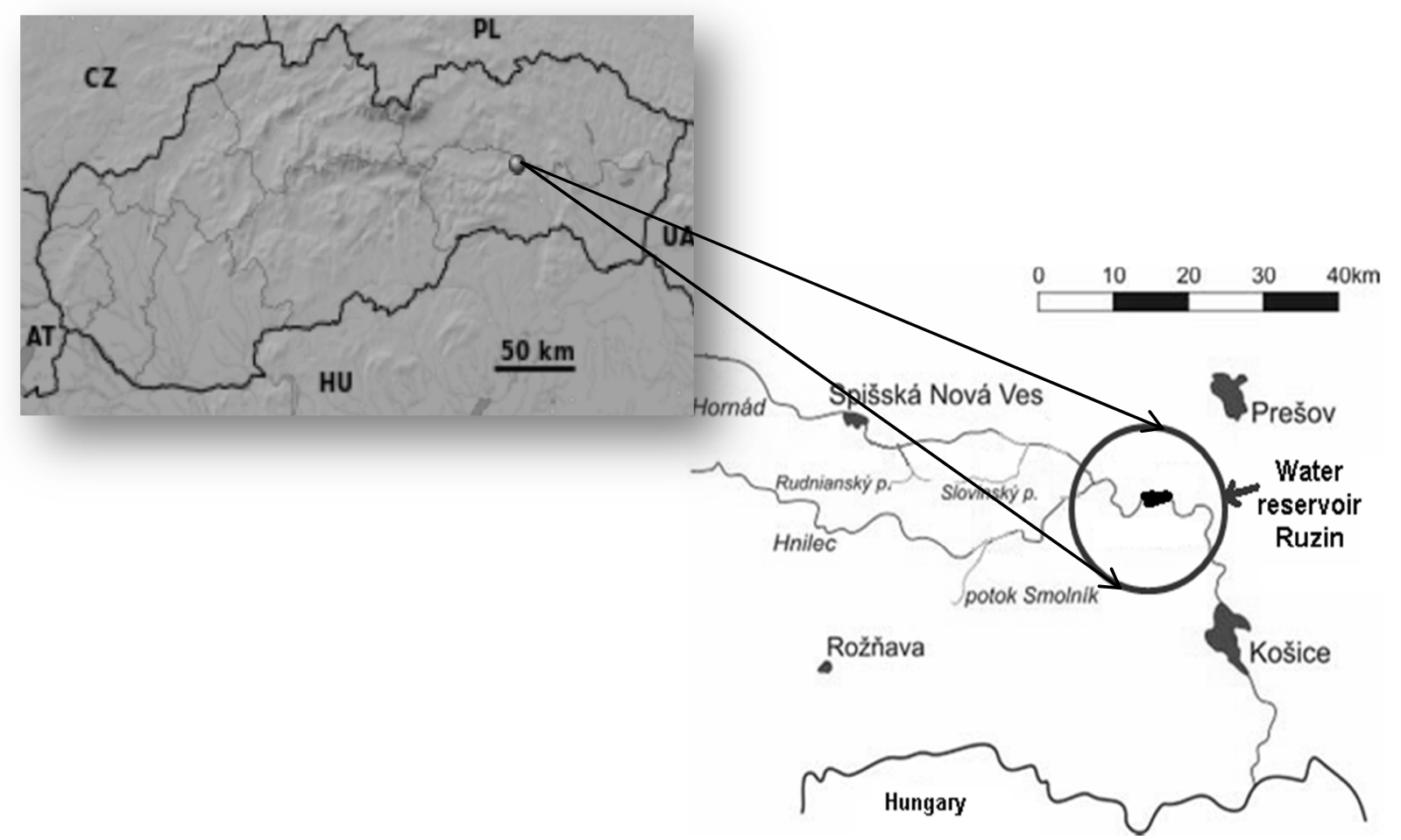

Fig. 1. Location of water reservoir Ruzin

\section{Materials and methods}

Sedimentswere sampledin 2012, due todeficiency of the rainthe water levelhas droppedby a fewmeters. In some placesthe water isnot locatedat all, onthis basis; itcan besampleddirectlystelesreservoiras shown Fig. 2. Sediments were sampled from surface $(0 \mathrm{~cm})$, from depth $20 \mathrm{~cm}$ and $50 \mathrm{~cm}$. 


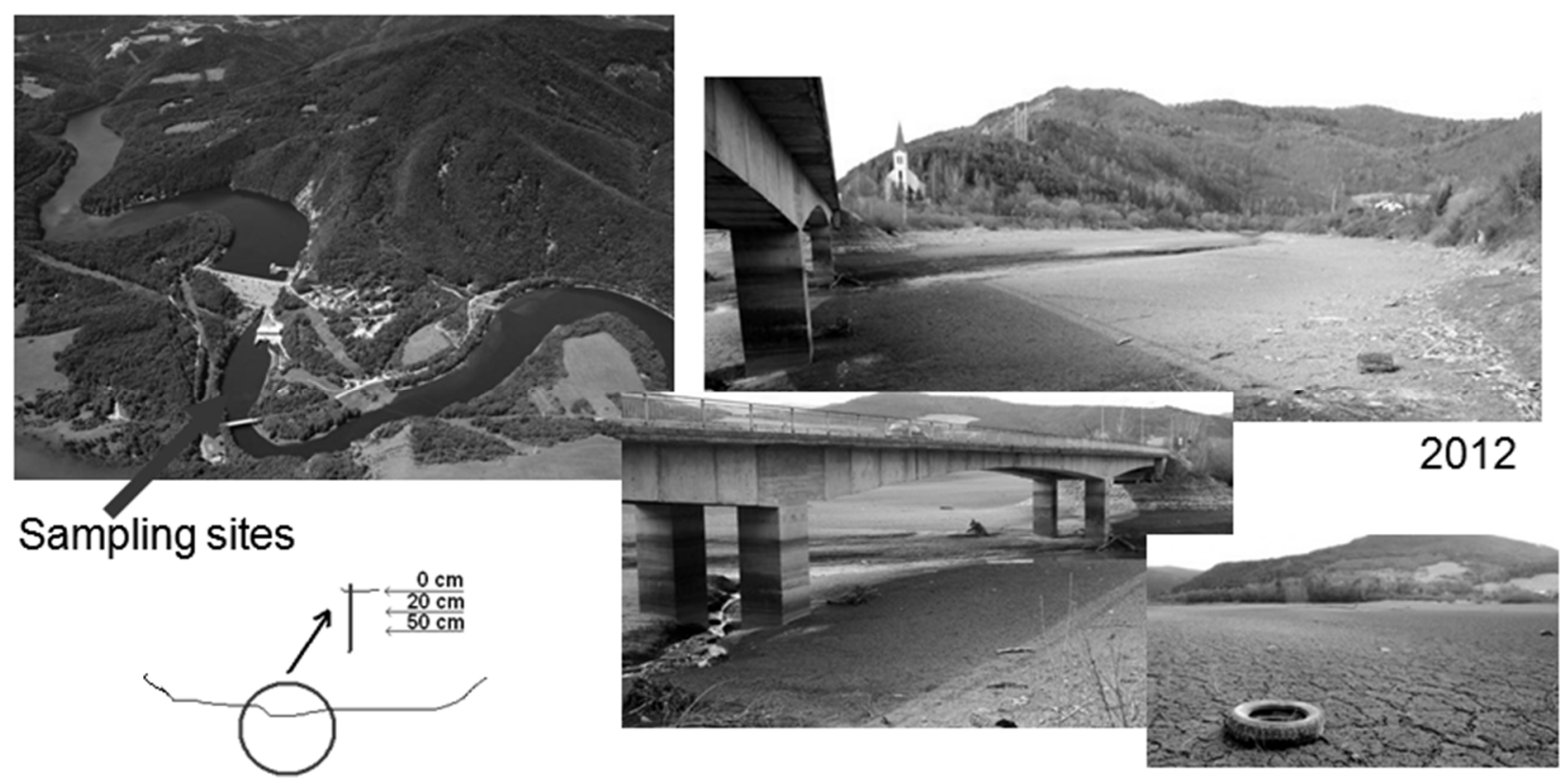

Fig. 2. Sediment sampling site in the Ruzin reservoir

The sediment was dried, homogenized and sieved bellow $0.063 \mathrm{~mm}$. Chemical analyses were realized by theXRF method using by SPECTRO iQ II (Ametek, Germany). The sediment samples were prepared as pressed tablets with diameter of $32 \mathrm{~mm}$ by mixing of $5 \mathrm{~g}$ of sample and $1 \mathrm{~g}$ of dilution material (M-HWC) and pressed at pressure of $0.1 \mathrm{MPa} / \mathrm{m} 2$.

\section{Results and discussion}

The degree of contamination in the sediments is determined with the help of two parameters - Enrichment factor (EF), Pollution load index (PLI).Assessment of contamination has been done on the basis of concentration values described the Table 1. As background concentrations the contents of selected elements in sediment unaffected by mining activities in assessment area were used.

Table 1. The results of chemical analysis of sediment

\begin{tabular}{|c|c|c|c|c|c|c|c|c|}
\hline \multirow{2}{*}{ Sample site } & $\mathrm{Fe}$ & $\mathrm{Mn}$ & $\mathrm{Al}$ & $\mathrm{Cu}$ & $\mathrm{Zn}$ & As & $\mathrm{Cd}$ & $\mathrm{Pb}$ \\
\hline & \multicolumn{3}{|l|}{$[\%]$} & \multicolumn{5}{|c|}{$[\mathrm{mg} / \mathrm{kg}]$} \\
\hline $0 \mathrm{~cm}$ & 4.62 & 0.14 & 6.65 & 245.5 & 321.1 & 22.9 & 5.1 & 59.4 \\
\hline $20 \mathrm{~cm}$ & 5.14 & 0.12 & 7.23 & 650.1 & 853.6 & 9.8 & 5.1 & 83.9 \\
\hline $50 \mathrm{~cm}$ & 5.64 & 0.12 & 6.97 & 959.2 & 906.5 & 27.1 & 2 & 73.9 \\
\hline Background & 4.64 & 0.10 & 8.14 & 190 & 174 & 19.8 & 0.5 & 60 \\
\hline
\end{tabular}

\subsection{Enrichment factor}

Enrichment factor calculation is a common approach to estimate anthropogenic impact on sediments. Mathematically expressed is as [13], [14]:

$$
E F=\frac{\left[M_{c} / M_{r}\right]_{s}}{\left[M_{c} / M_{r}\right]_{b}},
$$

where: $M_{c}$ is the content of contamination; $M_{r}$ is the content of reference elements; $s$ is the sample, and $\mathrm{b}$ is the background. A reference element is often used as a conservative element [13], [14]. In this study, Mn is used as a reference element, it has the least impact on the concentration of metals in sediments. The enrichment factor scale consists of six grades ranging, how show the Table 2 . 
Table 2. The enrichment factor scale [13]

\begin{tabular}{ll}
\hline EF $\leq 1$ & background concentration \\
\hline EF $1-2$ & deficiency to minimal enrichment \\
\hline EF 2-5 & moderate enrichment \\
\hline EF $5-20$ & significant enrichment \\
\hline EF 20-40 & very high enrichment \\
\hline EF $>40$ & extremely high enrichment \\
\hline
\end{tabular}

In order to assess the metal content in river sediments, it is important to establish the natural levels of these metals. Apart from natural contribution, heavy metals may be incorporated into the aquatic system from anthropogenic sources such as solid and liquid wastes of industries [15].

The EF values for every sample site are given in the Table 3. The table shows depletion trend for $\mathrm{Fe}, \mathrm{Cu}$ and $\mathrm{Al}(<1)$ for sample site in $0 \mathrm{~cm}$. The depletion trend is reflected for $\mathrm{Pb}$ for each sample sites. The $\mathrm{EF}$ for $\mathrm{Cu}$ and $\mathrm{Zn}(20 \mathrm{~cm})$ and $\mathrm{Fe}, \mathrm{Cu}$, $\mathrm{Zn}(50 \mathrm{~cm})$ is about minimal enrichment, while in case $\mathrm{Cd}(20 \mathrm{~cm})$ is shown significant enrichment. Very high enrichment (EF 20-40) constitutesAs in depth $20 \mathrm{~cm}$ with value 37,164. Cd and As in depth $50 \mathrm{~cm}$ shows very high EF values (> 40).

Table 3. Enrichment factor values of heavy metals in water reservoir Ruzin bed sediments

\begin{tabular}{ccccccccc}
\hline & $\mathrm{Fe}$ & $\mathrm{Mn}$ & $\mathrm{Al}$ & $\mathrm{Cu}$ & $\mathrm{Zn}$ & $\mathrm{As}$ & $\mathrm{Cd}$ & $\mathrm{Pb}$ \\
\hline $0 \mathrm{~cm}$ & 0.701 & 1 & 0.910 & 0.909 & 1.299 & 0.814 & 7.183 & 0.692 \\
\hline $20 \mathrm{~cm}$ & 0.954 & 1 & 1.212 & 2.949 & 3.221 & 37,164 & 16.897 & 0.073 \\
\hline $50 \mathrm{~cm}$ & 1.069 & 1 & 1.190 & 4.436 & 4.844 & 40,230 & 47.627 & 0.029 \\
\hline
\end{tabular}

\section{Pollution load index}

The pollution load index, proposed by Thomlinson et al. [16], was calculated using following equation:

$$
P L I=\left(C F_{1} \times C F_{2} \times C F_{3} \times \ldots \ldots \ldots \ldots . . . . \times F_{n}\right)^{1 / n},
$$

where $n$ is the number of the metals (eleven in the present study) and $C F$ is the contamination factor. The contamination factor can be calculated from the following relation:

$$
C F=\frac{\text { Metal concentration in the sediment }}{\text { Background value of the metal }}
$$

The contamination factor scale shows the Table 4 .

Table 4. The contamination factor scale [13]

\begin{tabular}{ll}
\hline $\mathrm{CF}<1$ & Low contamination \\
\hline $1 \leq \mathrm{CF} \leq 3$ & Moderate contamination \\
\hline $3 \leq \mathrm{CF} \leq 6$ & Considerable contamination \\
\hline $\mathrm{CF}>6$ & Very high contamination \\
\hline
\end{tabular}

Table 5. Contamination factor (CF) values and pollution load index (PLI) of metals in the sediment of water reservoir Ruzin

\begin{tabular}{ccccccccccc}
\hline & $\mathrm{Fe}$ & $\mathrm{Mn}$ & $\mathrm{Al}$ & $\mathrm{Cu}$ & $\mathrm{Zn}$ & $\mathrm{As}$ & $\mathrm{Cd}$ & $\mathrm{Pb}$ & \\
\hline \multicolumn{7}{c}{$\mathrm{CFI}$} \\
\hline $0 \mathrm{~cm}$ & 0.99 & 1.42 & 1.29 & 1.29 & 1.85 & 1.15 & 10.2 & 0.99 & 6.36 \\
\hline $20 \mathrm{~cm}$ & 1.11 & 1.16 & 1.41 & 3.42 & 4.91 & 0.49 & 10.2 & 1.39 & 26.74 \\
\hline $50 \mathrm{~cm}$ & 1.22 & 1.14 & 1.136 & 5.05 & 5.21 & 1.37 & 4.00 & 1.23 & 41.61 \\
\hline
\end{tabular}


The PLI is able to give an estimate of the metal contamination status and the necessary action should be taken a PLI $<1$ denote perfection; PLI $=1$ present that only baseline levels of pollutants ate present and PLI $>1$ would indicate deterioration of site quality [16].

The results of contamination factors and pollution index show the Table 5.Contamination factor for Fe $(0 \mathrm{~cm})$, and As $(20 \mathrm{~cm})$ indicate low contamination. The $\mathrm{CF}$ for each elementexcept $\mathrm{Cu}$ and $\mathrm{Zn}(20 \mathrm{~cm}$ and $50 \mathrm{~cm})$ shows moderate contamination. $\mathrm{Cu}$ and $\mathrm{Zn}$ show considerable contamination $(3 \leq \mathrm{CF} \leq 6)$. The high PLI values $6.36(0 \mathrm{~cm}), 26.74(20 \mathrm{~cm})$ and $41.61(50 \mathrm{~cm})$ indicated strong signs of pollution deterioration for each sampling sites.

\section{Conclusion}

Identification and quantification of heavy metal sources,as well as the fate of those heavy metals, are importantenvironmental scientific issues. The presented study gives the useful tools, methods, and indices for the evaluation of sediment contamination. Sediment pollution in this study wasassessed using Enrichment factor (EF) which shown significant enrichment of elements such as $\mathrm{Cd}(50 \mathrm{~cm})$ and mild enrichment for elementsAs and $\mathrm{Cd}$. The higher $\mathrm{Cd}$ value indicated that the sediments were enriched by anthropogenic activity. The very high values of PLI indicate deterioration of site quality.

The data obtained from this study will become part of baseline data and also important to the environmental agency as a policymaker for proper environmental management. This study also provide initial information to the relevant agencies and authorities in preparing preventive plan to control of heavy metals and other pollution from industries against direct discharge into the rivers.

\section{Acknowledgements}

This work has been supported by the Slovak Research and Development Agency under the contract No. APVV-0252-10 and by the Slovak Grant Agency for Science (Grant No. 1/0882/11).

\section{References}

[1] Bibi, M. H.; Faruque, A.; Hiroaki, I. 2006. Assessment of metal concentrations in lake sediments of southwest Japan based on sediment quality guidelines, Environmental Geology 52(4): 1-15.

[2] Hun-Bok, J.; Seong-Tack, Y.; Bernhard, M.; Soon-Oh, K.; Seong-Sook, P.; Pyeong-Koo, L. 2005. Transport and sediment-water partitioning of trace metals in acid mine drainage: an example from the abandoned Kwangyang Au-Ag mine area, South Korea, Environmental Geology 48: 437-449. http://dx.doi.org/10.1007/s00254-005-1257-7

[3] Singovszka, E.; Balintova, M. 2009. Methods of environmental risk assessment in water management, Pollack Periodica 4(1): 105-109. http://dx.doi.org/10.1556/Pollack.4.2009.1.11

[4] Holub, M.; Balintova, M. 2013. Testing of various sorbents for copper sorption from acidic solutions, Pollack Periodica 8(2): 47-54. http://dx.doi.org/10.1556/Pollack.8.2013.2.6

[5] Balintova, M.; Singovszka, E.; Holub, M. 2012 Qualitative Characterization of Sediment from the Smolnik Creek Influenced by acid mine drainage, in Procedia engineering: $20^{\text {th }}$ International congress of Chemical and Process Engineering CHISA, Prague. 42: 1654-1661.

[6] Karbassi, A. R.; Nouri, J.; Ayaz, G. O. 2007. Flocculation of trace metals during mixing of Talar River Water with Caspian Seawater, International Journal of Environmental Research 1(1): 66-73.

[7] Wang, F.; Chen, J. 2000. Relation of sediment characteristics to trace metal concentrations: a statistical study, Water Research 34(2): 694-698. http://dx.doi.org/10.1016/S0043-1354(99)00184-0

[8] Praveena, S. M.; Aris, A. Z.; Radojevic, M. 2010. Heavy metals dynamics and source in intertidal mangrove sediment of Sabah, Environment Asia, Borneo Island 3: 9-83

[9] Lintnerova, O.; Sottnik, P.; Soltes, S. 2008. Abandoned Smolnik mine (Slovakia) - a catchment area affected by mining activities, Estonian Journal of Earth Sciences 57(2): 104-110. http://dx.doi.org/10.3176/earth.2008.2.06

[10] Mmolawa, K. B.; Likuku, A. S.; Gaboutloeloe, G. K. 2011. Assessment of heavy metal pollution in soils along major roadside areas in Botswana. African Journal of Environmental Science and Technology5(3): 186-196.

[11] Luptakova, A.; Špaldon, T.; Bálintová, M. 2007. Remediation of acid mine drainage by means of biological and chemical methods, Advanced Materials Research: Biohydrometallurgy: From the Single Cell to the Environment (20-21): 283-286.

[12] Šottník, P.; Dubíková, M.; Lintnerová, O.; Rojkovič, I.; Šucha, V.; Uhlík, P. 2002. The links between the physico-chemical character of different mining waste in Slovakia and their environmental impacts, Geologica Carpathica (53): 227-228.

[13] Sutherland, R. A. 2000. Bed sediment - associated trace metals in an urban stream, Environmental geology, 611-637. Oahu, Hawai. http://dx.doi.org/10.1007/s002540050473

[14] Huu, H. H.; et al. 2010. Distribution and contamination status of heavy metals in estuarine sediments near Cau Ong harbor, Geology Belgica, 37-47. Ha Long Bay, Vietnam.

[15]Chakravarty, M.; Patgiri, A.D. Metal pollution assessment in sediments of the Dikrong river, N.E. India, available on the internet: http://www.krepublishers.com/02-Journals/JHE/JHE-27-0-000-09-Web/JHE-27-1-000-09-Abst-PDF/JHE-27-01-063-09-1769-Chakravarty-M/JHE27-01-063-09-1769-Chakravarty-M-Tt.pdf

[16]Thomilson, D. C.; Wilson, J.G.; Harris, C. R.; Jeffrey, D. W. 1980. Problems in assessment of heavy metals in estuaries and the formation of pollution index, Helgol Meeresunlters 33: 566-575. http://dx.doi.org/10.1007/BF02414780 